\title{
DIET AND FEEDING BEHAVIOR OF THE HORNED GUAN (OREOPHASIS DERBIANUS) IN MEXICO
}

\author{
FERNANDO GONZÁLEZ-GARCÍA, ${ }^{1,2,3,8}$ EDUARDO SANTANA-C., ${ }^{4}$ PEDRO D. JORDANO \\ BARBUDO, ${ }^{5}$ VICTOR RICO-GRAY, ${ }^{6}$ AND VICENTE URIOS MOLINER ${ }^{7}$
}

\begin{abstract}
The Horned Guan (Oreophasis derbianus) is endemic to humid montane forests of southern Mexico and Guatemala. This species is considered endangered because of their small populations, the loss and fragmentation of habitat, illegal trade, and overexploitation by subsistence hunters. We update information about the species' diet and foraging behavior by integrating the results generated during two and a half decades of research on the Horned Guan's ecology at the El Triunfo Biosphere Reserve, in Chiapas, Mexico, with additional published information compiled from other areas. Based on nearly $450 \mathrm{hrs}$ of direct observations of free-ranging guans and 530 discrete feeding events, we found that during the breeding season Horned Guans feed primarily on fruits from six species of plants and leaves from one species. Horned Guans were not observed eating animal matter, corroborating its specialized frugivore-folivore habits. Our study increases the known plant taxa found in the Horned Guan's diet in El Triunfo from 40 to 63 (Supplemental Material), and globally to 101 species (Supplemental Material). For 48 taxa in El Triunfo, only fruits were consumed, while for eleven taxa consumption was restricted to leaves, and to flowers for one species; for four taxa both fruits and leaves were consumed. We found significant differences between males and females in the location of foraging on trees and diet composition. Young birds are fed fruits of Citharexylum mocinnii and leaves of Solanum appendiculatum by their mothers, both of which are rare in the diet of adult males. The conservation of the Horned Guan requires the long-term protection of suitable habitat that maintains the plant species important in their diet. Received 21 March 2016. Accepted 18 January 2017.
\end{abstract}

Key words: conservation of Neotropical montane forest birds, El Triunfo Biosphere Reserve, foraging behavior, frugivory, Horned Guan, Mexican cloud forest, Oreophasis derbianus.

The Horned Guan (Oreophasis derbianus) is endemic to the humid montane forest of southern Mexico and Guatemala (Andrle 1967, Howell and Webb 1995, del Hoyo and Motis 2004). At the global level, the species is currently considered endangered (Brooks 2006, BirdLife International

\footnotetext{
${ }^{1}$ Red Biología y Conservación de Vertebrados. Instituto de Ecología, A.C. Carretera Antigua a Coatepec No. 351, El Haya, Xalapa, Veracruz, México.

${ }^{2}$ Departamento de Ciencias Ambientales y Recursos Naturales, Facultad de Ciencias, Universidad de Alicante. Carretera San Vicente del Raspeig s/n, San Vicente del Raspeig, Alicante, 03690, Spain.

${ }^{3}$ Centro Interdisciplinario de Investigación para el Desarrollo Integral Regional Unidad Oaxaca (CIIDIR), Instituto Politécnico Nacional, Calle Hornos 1003, Col. Santa Cruz Xoxocotlán, C.P. 71236. Oaxaca, México.

${ }^{4}$ Instituto Manantlán de Ecología y Conservación de la Biodiversidad. Departamento de Ecología y Recursos Naturales, Centro Universitario de la Costa Sur, Universidad de Guadalajara. Av. Independencia Nacional 151, Autlán de Navarro, Jalisco, México. 48900.

${ }^{5}$ Estación Biológica de Doñana, CSIC, Isla de la Cartuja, Avda. Americo Vespusio S/N E-41092, Sevilla, Spain.

${ }^{6}$ Instituto de Neuroetología, Universidad Veracruzana. Av. Luis Castelazo Ayala s/n. Col. Industrial Animas. Xalapa, Veracruz, 91190 México.

${ }^{7}$ Universidad de Alicante. Campus San Vicente del Raspeig, Edificio Ciencias III, Alicante, 03080 Spain.

${ }^{8}$ Corresponding author; email: fernando.gonzalez@inecol.mx
}

2015), because of small population sizes and threats from hunting, deforestation, and illegal trade (CONAP 2001, Eisermann and Avendaño 2006, SEMARNAT 2010, BirdLife International 2015, del Hoyo and Kirwan 2015). Although there are many published descriptions of its biology and ecology in the wild and in captivity (Álvarez del Toro 1976; González-García 1984, 1986, 1988, 1991, 1994, 1995, 1997a, b, c, 2001, 2005a, b, 2007, 2009; González-García and Bubb 1989; Gómez de Silva G. et al. 1999; Méndez 2000, 2010; González-García et al. 2001，2006a, b; Secaira and Cornejo 2003; Montes 2005; Pozo V. et al. 2005; Rivas Romero and Cóbar Carranza 2005, 2007; Rivas-Romero et al. 2005; Secaira 2005; Abundis 2006; Eisermann et al. 2007; Secaira and Cornejo 2007; Tovar et al. 2007, 2009; Cornejo 2009; Dierenfeld et al. 2009; Ramos and GonzálezGarcía 2009), important aspects of its ecology are still unknown (e.g., home range and seasonal and patterns of movements).

Taxonomically, this species is placed in a monotypic genus, Oreophasis, and individuals have a 'horn' (naked coral-red bony structure growing on top of the head). It is one of the few bird species that feeds predominantly on fruits and leaves, as well as nectar and flowers (Klasing 1998, Muñoz and Kattan 2007, Rivas Romero 2008, Méndez 2010). 
An ecologically relevant characteristic is that many of the seeds consumed pass through the digestive tract unharmed, defecated in viable condition with different species-specific rates of germination (González-García 2009, Ramos and González-García 2009). Horned Guans are considered to play an important role as seed dispersers, affecting the composition and structure of cloud forests (Silva and Strahl 1991, Sedaghatkish 1996, Muñoz and Kattan 2007). Because of their large size, movements and specialized diet, information on plant-animal interactions, such as seed dispersion and effects on forest dynamics are relevant for understanding the structure and function of the endangered montane forest ecosystems they inhabit (Howe et al. 1985, Strahl and Grajal 1991, Jordano 2007). In their assessment of available information on cracid diets, Muñoz and Kattan (2007) concluded that "few rigorous quantitative studies on cracid diets are available" and few studies had "evaluated seasonal and habitat variations in resource availability and cracid responses to such variation." This missing information is essential for understanding aspects of the Horned Guan's ecology, behavior, population dynamics, and habitat requirements needed to develop conservation management recommendations. Consequently, there is a need for an updated assessment of the Horned Guan's diet and ecology and its relationship to seasonal fruit availability (Muñoz and Kattan 2007). We synthesize published information on the Horned Guan's diet and foraging ecology, seasonal fruit production and reproductive phenology from Mexico and Guatemala (González-García 1984, 1991, 1994, 2005a, 2007, 2009; Solórzano 1995; Méndez 2000, 2010; Solórzano et al. 2000; Dierenfeld et al. 2009; Ramos and González-García 2009; Quiñónez Guzmán 2011; Rivas-Romero and Soto-Shoender 2015), and analyze unpublished foraging observations from the El Triunfo Biosphere Reserve collected 1982-2006 and 2011-2014 to provide a reassessment of the diet and foraging behavior of the Horned Guan in Mexico.

\section{METHODS}

The El Triunfo Biosphere Reserve is located in the central portion of the Sierra Madre de Chiapas $\left(15^{\circ} 09^{\prime} 10^{\prime \prime}\right.$ and $15^{\circ} 57^{\prime} 02^{\prime \prime} \mathrm{N}, 92^{\circ} 34^{\prime} 04^{\prime \prime}$ and $\left.93^{\circ} 12^{\prime} 42^{\prime \prime} \mathrm{W}\right)$. The El Triunfo Biosphere Reserve (450 to $2,750 \mathrm{~m}$ ) has a total area of 119,117 ha, including one of the most extensive $(\sim 50,000$ ha) contiguous areas of mesophilous forest in Mexico (Challenger 1998, INE 1999). Annual precipitation ranges from 2,000 and $4,500 \mathrm{~mm}$ and annual average temperature between $14-30{ }^{\circ} \mathrm{C}$, with a relative dry season between November and April and a rainy season from May to October (INE 1999).

El Triunfo reserve harbors 10 vegetation types; the dominant ones being the mesophilous mountain ('cloud') forest, tropical humid ('rain') forest, and pine-oak forest. Tropical deciduous forests are found along the bottom of ravines and of sheltered hillsides at lower altitudes (INE 1999). The reserve is divided into five core zones. Our research was conducted in the 11,594 ha Zone I, El Triunfo (INE 1999). In El Triunfo, the Horned Guan is restricted to mesophilous mountain forest. Zone I Cloud forest (altitude range 1,700-2,400 m) is characterized by the Quercus-Matudaea-Hedyosmun-Dendropanax community (Ramírez and Williams Linera 1990; Long and Heath 1991; PérezFarrera et al. 2004; González-García 2005a, b), although it can use other forest types at lower altitudes seasonally. A detailed description of the plant species composition and structure of the Horned Guan's preferred habitat in El Triunfo Biosphere Reserve was conducted by FG-G (unpubl. data), and a similar study is known for Volcán San Pedro, Sololá, Guatemala (Pardo Villegas 2007).

We observed foraging behavior and diet of Horned Guans mostly during the reproductive season from February to May of 1982-1984, 1987-1992, January-June and August-December 1993. No field work was conducted during July and August 1993. Our searches covered $861.8 \mathrm{~km}$ on trails within a $2.6 \pm 0.65 \mathrm{~km}$ (mean $\pm \mathrm{SD}, n=$ 6 trails) radius of the main visitors' camp. Guans were usually found by the sounds they made during courtship or foraging (e.g., wing flapping, defecating) and by visiting trees known to be used regularly for foraging. Our systematic search of the study area assured that we were able to detect shifts in diet when guans began feeding on new species of trees, and the systematic quantification of our observations allowed us to objectively compare the diet of males and females as well as adults and young. Our data will be slightly biased towards the most commonly used species, and thus should be interpreted as a first approximation to 
quantifying the relative frequency of plant species in the diet of Horned Guans. Guans were more easily detected from early October to May when courting males perform deep, slow and soft 7-note "mooing" courtship calls to attract females, and perform conspicuous short flights from tree to tree (González-García 1995, Gómez de Silva G. et al. 1999). Beak-clacking, the only one of 13 described calls that is similar among males and females, is also heard during this period. We observed foraging, diet, and courtship behavior with $10 \times$ 40 binoculars or a $18-36 \times 50 \mathrm{~mm}$ telescope from distances of 10 to $50 \mathrm{~m}$. Length of events were measured with digital watches or chronometers from direct observations in the field.

Data on foraging behavior come from $449.5 \mathrm{hrs}$ of observation $(885.5 \mathrm{hrs}$ of search time conducted during Feb to May of 1987-1992 and during Jan-Jun and Aug-Dec 1993: mean $8.79 \pm 2.47$ $\mathrm{hr} /$ day) with a mean of $3.15 \pm 2.92 \mathrm{hrs}(1-590$ mins) of continuous daily observation over 101 days. Mean observation per individual was 2.96 \pm 2.65 hrs. We observed 520 foraging behavior events of which we recorded 263 events by females, 208 events by males, and 49 events by individuals of unknown sex. Additional data on diet and feeding behavior were gathered during observation conducted during March 2011-January 2012, February 2012-January 2013, February 2013-April 2014 as part of long-term monitoring programs for Horned Guans. The observation method used was based mainly on ad libitum and all occurrences sampling during opportunistic encounters. Using that sampling method, we gathered data on frequencies and durations of behaviors for single guans, pairs ( 1 pair $=1$ male and 1 female), or females with chicks or juveniles were recorded during different sampling periods (Altmann 1974, Martin and Bateson 1986, Lehner 1996).

Although birds were not individually marked, based on individual differences in plumage characteristics, body size, and shape of horn, as well as the locations and time of the observation, our data are based on 15-18 different males, 12-14 different females, and 10-13 different chicks or juveniles. We determined the diet by identifying field-collected specimens of the flowers, fruits and leaves of the plants on which the guans were feeding, and by identifying seeds collected from fecal samples.
We recorded: 1) Total time guans were observed on a given tree species; 2) Total time guans were observed feeding on a given tree species; and 3) Frequency of occasions guans were observed feeding on a given fruit species. These three parameters were highly correlated: total time spent in a tree species versus duration of feeding time observed on that species of tree $\left(r^{2}=0.90, P<\right.$ $0.001, \mathrm{df}=19)$ and versus frequency of occasions observed feeding in that tree species $\left(r^{2}=0.88, P\right.$ $<0.001, \mathrm{df}=19)$; time observed feeding and the number of occasions observed feeding in the same tree species $\left(r^{2}=0.85, P<0.001\right.$, df $\left.=19\right)$. However, there is no relationship between the total time spent in a tree species and the percentage of time spent foraging on that tree species $\left(r^{2}=\right.$ $0.0523, P=0.32$, df $=19$ ). Given the high correlation among the three parameters we used, we were able to more easily analyze the frequency of feeding events to evaluate the diet of Horned Guans.

We compared the seasonal phenology of fruit production (Solórzano 1995, Solórzano et al. 2000) with the diet and reproductive cycle of the guans. Student's $t$-test and non-parametric tests ( $\mathrm{X}^{2}$, Mann-Whitney $U$-test) were used to evaluate the level of significance of the comparisons. Most data are presented as mean \pm SD and median for the total time spent in the trees and duration of feeding visits. All tests were performed using Statistica (StatSoft Inc. 2003).

\section{RESULTS}

We observed 520 foraging events on 21 plant taxa, $83 \%$ of the observations consisted of only fruits, $17 \%$ of only leaves, and $1 \%$ of leaves and fruits of the same species and flowers. Consumed fruits were mostly ripe, but occasionally during the breeding season, unripe fruits were eaten. Leaves were only consumed at young tender stages. We tallied more than 500 mins of feeding observations at trees (see below), the mean \% foraging time of the total time spent on a tree was $28.3 \pm 7.3$ mins.

Horned Guans fed most frequently on seven taxa (Table 1), with $50 \%$ of the feeding observations occurring evenly on two species: Symplococarpum purpusii and Citharexylum mocinnii. Morus insignis, Dendropanax sp., Conostegia volcanalis, and Hedyosmun mexicanum each 
TABLE 1. Feeding observations of Horned Guans Oreophasis derbianus by age and during courtship feeding in the El Triunfo Biosphere Reserve, Chiapas, Mexico.

\begin{tabular}{|c|c|c|c|c|}
\hline \multirow[b]{2}{*}{ Species plants } & \multicolumn{4}{|c|}{ Frequency of observations } \\
\hline & $\begin{array}{l}\text { Adult Horned Guans } \\
\qquad N(\%)\end{array}$ & $\begin{array}{c}\text { Chicks and fledglings } \\
N(\%)\end{array}$ & $\begin{array}{c}\text { Courtship feeding } \\
N(\%)\end{array}$ & $\begin{array}{c}\text { Total } \\
N(\%)\end{array}$ \\
\hline Symplococarpum purpusii & $108(25.4)$ & & $21(67.7)$ & $129(25.4)$ \\
\hline Citharexylum moccinii & $90(21.2)$ & $33(62.2)$ & & $123(24.2)$ \\
\hline Solanum appendiculatum & $63(14.8)$ & $7(13.2)$ & & $70(13.8)$ \\
\hline Morus insignis & $53(12.5)$ & & $4(12.9)$ & $57(11.2)$ \\
\hline Hedyosmun mexicanum & $26(6.1)$ & & & $26(5.1)$ \\
\hline Conostegia volcanalis & $25(5.8)$ & & $1(3.2)$ & $26(5.1)$ \\
\hline Dendropanax sp. & $22(5.1)$ & $11(20.7)$ & $2(6.4)$ & $35(6.9)$ \\
\hline Other species* & $37(8.7)$ & $2(3.7)$ & $3(9.6)$ & $42(8.3)$ \\
\hline Total & $424(100)$ & $53(100)$ & $31(100)$ & $508(100)$ \\
\hline
\end{tabular}

* Other species with < 9 observations: Trophis cuspidata, Prunus sp., Amphitecna montana, Lauraceae, Ocotea chiapensis, Urera caracasana, Cestrum aff. guatemalae, Ugni myricoides, Spathacanthus parviflorus, Nectandra rudis, Quercus sp., Prunus brachybotrya, Licaria excelsa/L. glaberrima.

contributed $5.1 \%$ to $11.2 \%$ of the observations. Horned Guans consumed leaves of Solanum appendiculatum during $13.8 \%$ of the observations. The use of the seven plants species varies significantly depending of age and courtship (adults: $\mathrm{X}^{2}=125.37, \mathrm{df}=6, P<0.001$; chicks and fledglings: $\mathrm{X}^{2}=121.8, \mathrm{df}=6, P<0.001$; courtship: $\left.\mathrm{X}^{2}=87.5, \mathrm{df}=6, P<0.001\right)$ (Table 1). Seeds of Ocotea chiapensis, Dendropanax sp., Oreopanax sp., Eugenia capulli, C. mocinnii, Urera caracasana, Smilax sp., S. purpusii, leaves of $S$. appendiculatum and P. brachybothrya, and other unidentified plant material were found in 12 different fecal droppings (average number of seeds per excrement was $101.5 \pm 85.17$, range $=1-342$, $n=12$ ). All seeds found in fecal samples were intact, suggesting that guans digest only pulp. No traces of arthropods or vertebrates were found (one dropping contained three small $(2-3 \mathrm{~mm})$ undigested white larvae that seemed to have colonized the dropping). Guan feces that include leaves generally included small pebbles. No pebbles were detected in feces without leaves. Feces often contained seeds of Dendropanax sp. and Smilax sp., and some whole fruits were undigested, suggesting gentle treatment during digestion or being consumed when unripe (Tables 2-3).

Guans consumed leaves from eleven taxa (Supplemental Material), the most frequent of those were $S$. appendiculatum and of P. brachybotrya, which they fed on during the breeding season and later. Leaves of the latter species were eaten whole or in fragments by males, females, chicks and juveniles. During 39 mins of observation in a P. brachybothrya tree, one male Horned Guan ate 179 times (4.6 leaves/min). One female and her two chicks were also observed feeding on green leaves of the same tree species. In total, at El Triunfo, the diet of guans is based on 63 plant species of 32 families (Supplemental Material).

Guans revisit the same plants or group of the same plants if they are bearing abundant fruit. Feeding visits can be on consecutive days and even in different months. For example, one female with one juvenile (age 4-5 months based on the horn size) revisited the same $P$. matudae tree with abundant fruit in October, November and December 2012. During $5.48 \mathrm{hrs}$ of observations, we observed this female with her juvenile feeding together on P. matudae tree. The female fed 13 times, the juvenile 18 times, and both produced 36

TABLE 2. Frequency and percentage of feeding events of male and female Horned Guans (Oreophasis derbianus) on the most important food trees in the El Triunfo Biosphere Reserve, Chiapas.

\begin{tabular}{lcrrr}
\hline Fruits species & Females & \multicolumn{1}{c}{$\%$} & Males & $\%$ \\
\hline Citharexylum moccinii & 72 & 45.6 & 13 & 7.5 \\
Symplococarpum purpusii & 24 & 15.2 & 83 & 48.0 \\
Morus insignis & 21 & 13.3 & 25 & 14.5 \\
Dendropanax sp. & 15 & 9.5 & 7 & 4.0 \\
Conostegia volcanalis & 12 & 7.6 & 10 & 5.8 \\
Hedyosmum mexicanum & 2 & 1.3 & 23 & 13.3 \\
Others & 12 & 7.6 & 12 & 6.9 \\
Total & 158 & 100.0 & 173 & 100.0 \\
\hline
\end{tabular}


TABLE 3. Reproductive phenology of the Horned Guans (Oreophasis derbianus) in the El Triunfo Biosphere Reserve, Chiapas, Mexico, based in all our sampling periods.

\begin{tabular}{|c|c|c|c|c|c|c|c|c|c|c|c|c|}
\hline \multirow[b]{2}{*}{ Reproductive activity } & \multicolumn{12}{|c|}{ Months } \\
\hline & Jan & Feb & Mar & Abr & May & Jun & Jul & Aug & Sept & Oct & Nov & Dec \\
\hline Courtship calls & • & • & • & • & • & • & & & & • & • & - \\
\hline Courtship feeding/following & • & • & • & - & - & & & & & • & - & \\
\hline Copulation & $\bullet$ & $\bullet$ & • & • & & & & & & & & \\
\hline Selection of nest sites & • & • & • & • & & & & & & & & \\
\hline Egg laying & • & • & • & $\bullet$ & & & & & & & & \\
\hline Incubation & • & • & • & • & • & & & & & & & \\
\hline Hatching/chicks/fledglings & • & • & • & $\bullet$ & • & • & • & • & & & & \\
\hline Care of fledglings and juveniles & & & - & • & • & • & - & • & • & • & - & • \\
\hline
\end{tabular}

feces. The female defecated every $15.3 \pm 11.20$ mins (range $=1-44, n=17$ ) and the juvenile defecated every $17.7 \pm 9.50$ mins (range $5-34, n$ $=17$ ). Feeding bouts (defined as the time of uninterrupted feeding) for the female lasted 10.3 \pm 10.6 mins (range $=2-35, n=11$ ) and for the juvenile lasted $5.5 \pm 2.6$ mins (range $=1-10, n=$ 14). A feeding bout began every $23.4 \pm 22.0 \mathrm{mins}$ (range $=1-67, n=10$ ) for this female, and for the juvenile it began every $17.8 \pm 13.9$ mins (range $=$ $1-36, n=13$ ). These and other observations on $C$. moccinni, C. volcanalis, and M. insignis fruiting trees (FGG, unpubl. data), suggest this cracid species remembers the location and the time of ripening of individual fruit trees (Galleti et al. 1997).

Male and female Horned Guans had significantly different $\left(\mathrm{X}^{2}=94.05, \mathrm{df}=5, P<0.001\right)$ diet composition, with males consuming a greater proportion of fruits $(91.3 \%$ versus $79.5 \%)$ and a lower proportion of leaves ( $7.7 \%$ versus $19.8 \%)$ than females (Table 2). Males fed more on fruits of $S$. purpusii and H. mexicanum and females fed more on fruits of $C$. mocinnii and Dendropanax sp. and leaves of $S$. appendiculatum. The three species preferred by females (C. mocinnii, Dendropanax sp., $S$. appendiculatum) were the principal food species fed to chicks and might reflect the dietary needs or preferences of the chicks rather than of the adult females. Four of the seven most important plant species in the diet (C. mocinnii, $S$. purpusii, M. insignis, $C$. volcanalis) were presented by males to females during courtship feeding (Tables 1-2).

Horned Guans are mainly arboreal and tend to forage in the mid strata of the forest, sometimes on the ground, and less frequently in the canopy. Horned Guans were observed in trees with a mean height of $19.03 \pm 5.3 \mathrm{~m}$ (range 7-40 $\mathrm{m}, n=$ 1,375), with the individuals located at a mean height of $14.8 \pm 4.7 \mathrm{~m}$ (range $=3-35 \mathrm{~m}, n=$ 1,375). Foraging locations differed between sexes (Fig. 1). Males used trees that were significantly taller $($ mean $=21.5 \pm 4.6 \mathrm{~m}$, range $=12-40 \mathrm{~m}, n$ $=510$ ) than those used by females (mean $=17.6 \pm$ $5.3 \mathrm{~m}$, range $=10-35 \mathrm{~m}, n=768)(t$-test $=11.90$, $\mathrm{df}=1,276, P<0.001)$. Males foraged significantly higher $($ mean $=16.7 \pm 4.3 \mathrm{~m}$, range $=8-35$ $\mathrm{m}, n=510$ ) than females (mean $=13.6 \pm 4.7 \mathrm{~m}$, range $=7-25 \mathrm{~m}, n=768)(t$-test $=13.58, \mathrm{df}=$ $1,276, P<0.001)$. Guans of unknown sex were

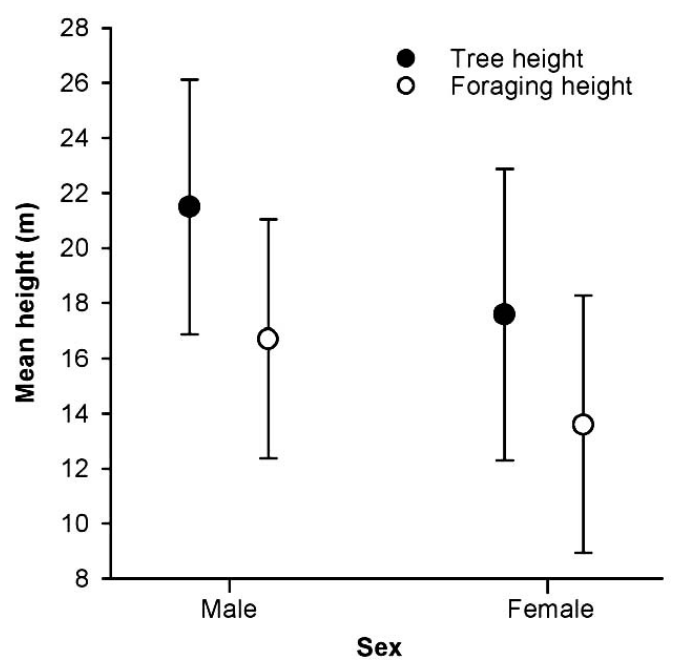

FIG. 1. Tree and foraging height of male and female of Horned Guans (Oreophasis derbianus) in the El Triunfo Biosphere Reserve, Chiapas, Mexico (Mean $\pm \mathrm{SD}$ ). 
TABLE 4. Monthly feeding observations of the Horned Guans (Oreophasis derbianus) in different plants species in the El Triunfo Biosphere Reserve, Chiapas, Mexico.

\begin{tabular}{|c|c|c|c|c|c|c|c|c|c|c|c|c|c|}
\hline \multirow[b]{2}{*}{ Species plants } & \multicolumn{13}{|c|}{ Months } \\
\hline & Jan. & Feb. & Mar. & Apr. & May. & Jun. & Jul.* & Aug.* & Sept. & Oct. & Nov. & Dec. & Total \\
\hline Symplococarpum purpusii & & 50 & 27 & 35 & 18 & & & & & & & & 130 \\
\hline Citharexylum moccinii & & & & 2 & 119 & 3 & & & & & & & 124 \\
\hline Solanum appendiculatum & & & 22 & 4 & 38 & 9 & & & 1 & & 1 & & 75 \\
\hline Morus insignis & & 10 & 46 & & 2 & & & & & & & & 58 \\
\hline Dendropanax sp. & & 4 & 1 & 6 & 27 & 1 & & & & & & & 39 \\
\hline Conostegia volcanalis & & 1 & 15 & & 12 & & & & & & & & 28 \\
\hline Hedyosmum mexicanum & & & & 15 & 6 & 5 & & & & & & & 26 \\
\hline Trophis cuspidata & & & & & & & & & & & 4 & 5 & 9 \\
\hline Prunus sp. & & & 3 & & 2 & & & & & & & & 5 \\
\hline Amphitecna montana & & & & & & & & & 1 & & 3 & & 4 \\
\hline Ocotea chiapensis & & 4 & & & & & & & & & & & 4 \\
\hline Lauraceae & & & 3 & & & & & & & & & & 3 \\
\hline Nectandra rudis & & & 2 & & & & & & & & & & 2 \\
\hline Cestrum aff. Guatemalense & & & 2 & & & & & & & & & & 2 \\
\hline Spathacanthus parviflorus & & & 2 & & & & & & & & & & 2 \\
\hline Ugni myricoides & & & & 2 & & & & & & & & & 2 \\
\hline Quercus sp. & & & 1 & & & 1 & & & & & & & 2 \\
\hline Licaria excels/L. glaberrima & & & & & & & & & & & & 1 & 1 \\
\hline Prunus brachybotrya & & & & & 1 & & & & & & & & 1 \\
\hline Undetermined & & & 1 & & 2 & & & & & & & & 3 \\
\hline Total observations & & 69 & 125 & 64 & 227 & 18 & & & 2 & & 8 & 7 & 520 \\
\hline
\end{tabular}

* Field work not conducted during July and August. Only in 1993 was field work done from Sept to Dec.

observed using trees with a mean height of $17.4 \pm$ $3.4 \mathrm{~m}$ (range 7-20 m, $n=97$ ) and foraging at a mean height of $13.8 \pm 2.5 \mathrm{~m}$ (range $=6-18 \mathrm{~m}, n=$ 97).

The reproductive phenology of the Horned Guan can be divided into eight behavioral categories each spanning 3-9 months (Table 3) and is clearly correlated with two ecological processes: rainfall and fruit production. Incubation and fledging occur from January to May which includes the driest months of the year (Jan to Mar) and the beginning of the rainy season (Apr and May). Although Horned Guans have been observed feeding on different species of fruits and leaves at El Triunfo during all 12 months of the year (Table 4, Supplemental Material), and at least 6 species of fruits are available for the guan to eat during the whole year (Solórzano et al. 2000), the most abundant species of fruits in their diet are produced during a restricted 3-7 month period from January to August that coincides with the reproductive season (e.g., C. mocinnii: Jan-Jun, $S$. purpusii: Nov-Apr, M. insignis: Feb-Mar, and $C$. volcanalis: Mar-Aug; Solórzano 1995, Solórzano et al. 2000).
During the reproductive period, guans fed on 5-12 species of fruits (Table 4). M. insignis was important early in the season (Feb and Mar) and C. moccini, Dendropanax sp., and S. appendiculatum at the end of the season when these species were consumed by females and fledglings (Table 1). Data on the average monthly abundance of 10 fruit species consumed by guans, including the four most important fruit species consumed during the breeding season, shows peak fruit availability occurring form February to April (Fig. 2; Solórzano 1995, Solórzano et al. 2000).

\section{DISCUSSION}

Our observations of foraging wild Horned Guans document 24 new plant species/taxa not previously observed in their diet in El Triunfo. Additionally, Horned Guans have been reported eating flowers of Arpophylum medium (Orchidaecae), Chiranthodendron pentadactylon (Malvaceae), and Clematis sp. (Ranunculaceae; González-García 2005a, b; Abundis Santamaría 2006; Rivas Romero 2008), drinking nectar from the flowers of $C$. pentadactylon (Méndez 2000, 


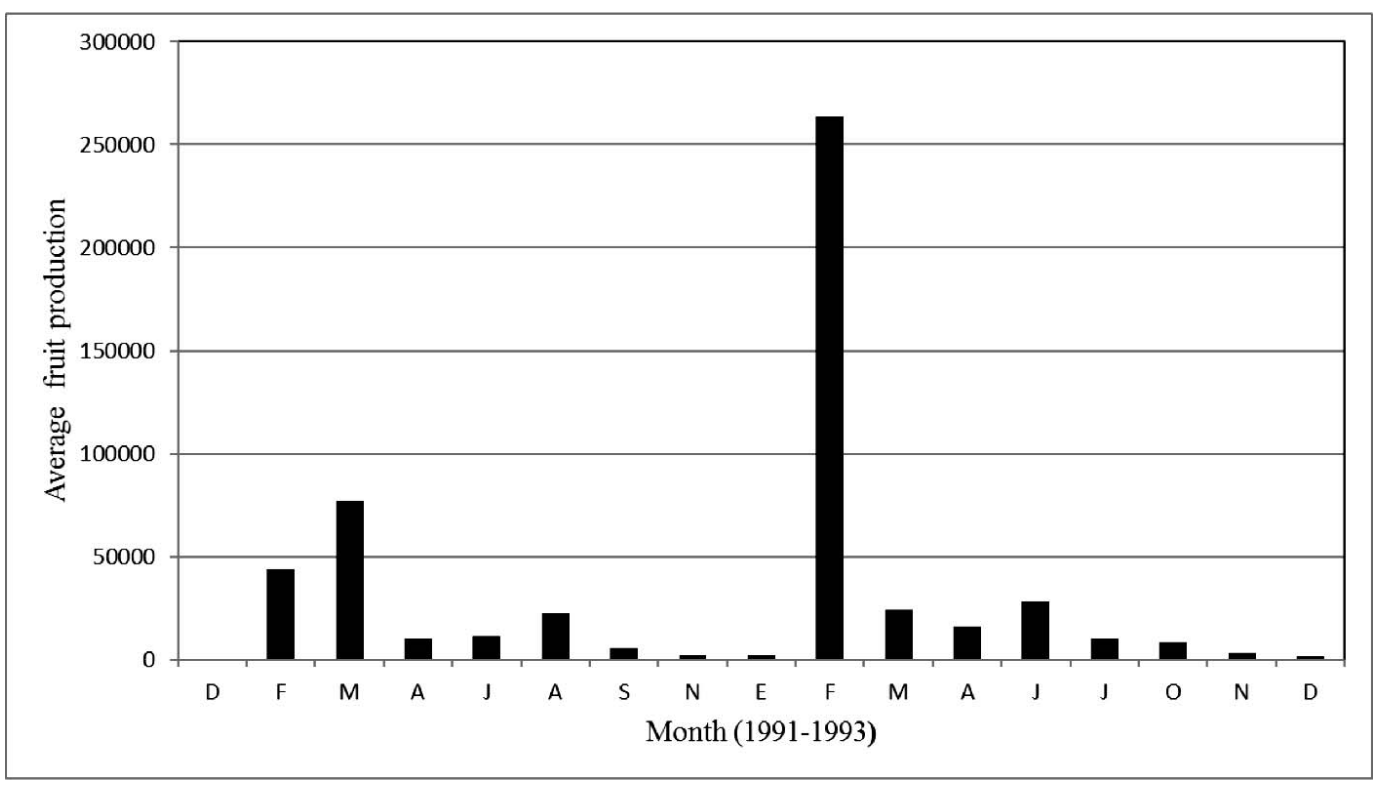

FIG. 2. Average monthly abundance of fruits of species common in the diet of the Horned Guan in El Triunfo Biosphere Reserve (pooled data from the following species: Citharexylum mocinnii, Conostegia volcanalis, Morus insignis, Ocotea chiapensis, Trophis cuspidata, Licaria excelsa/Licaria glaberrima, Nectandra rudis, Cinnamomun zapatae, Symplococarpon purpusii). Data adapted from Solórzano (1995).

2010; Cóbar Carranza 2006; Rivas Romero 2008; FG-G, pers. obs.), and feeding on fruits of Oreopanax echinops, Dendropanax arboreus (Araliaceae), and Phoebe salvini (Lauraceae; Méndez 2000, 2010; Rivas Romero 2008). Additional plants recorded in their diet are shown in Supplemental Material, which excludes an unconfirmed report of Horned Guans eating leaves of watercress (Nasturtium officinale: Brassicaceae) by villagers from Chiquihuite (Volcán Tacaná), in Unión Juárez, Chiapas). The known plant taxa consumed by Horned Guans is 101 range-wide (Méndez 2000, 2010: appendix II; Montes 2005; Cóbar Carranza 2006; Pardo Villegas 2007; Supplemental Material) and 63 at El Triunfo (del Hoyo and Motis 2004; González-García 2005a, b; Supplemental Material). We confirm the diet of Horned Guans is almost exclusively based on fruits, leaves, flowers and nectar, and that they consume different plant parts according to the species (Supplemental Material).

During the breeding season, Horned Guans concentrate their diet on seven species that are relatively common in El Triunfo (Long and Heath 1991, Williams Linera 1991, Gómez Velasco et al. 2004). However, the frequencies of the preferred species in Horned Guans' diet are not related to their abundance in the El Triunfo cloud forest, as other fruiting trees were more abundant in the forest than those of S. purpusii, C. mocinnii, and $M$. insignis which were preferred by the guans (González-García 2005a). Lauraceous plants were not as important in the diet of Horned Guans as we expected because Lauraceous fruits, rich in lipids and nutrients, have been shown to constitute an important component of the diet of many large frugivorous species in humid montane forests of the Neotropics, including the El Triunfo forest (Moermond and Denslow 1985, Wheelwright 1991, González-García 1994, Solórzano 1995, Solórzano et al. 2000, Muñoz and Kattan 2007, Bertsch and Barreto 2008).

The pattern of concentrating their diet on only a few species of fruits has been reported in other guan species such as Penelope superciliaris (Mikich 2002, Zaca et al. 2006), P. obscura (Merler et al. 2001), P. marail (Thery et al. 1994, Muñoz et al. 2007), Chamaepetes goudotii (Londoño et al. 2007), and curassows such as Crax daubentoni (Bertsch and Barreto 2008). Other cracids have also been reported to depend on a few plant species such as Mitu mitu in Peru 
(four species of Moraceae: Brosinum sp., Clarisia racemosa, Ficus sp., and Pseudolmenia sp.; Torres 1989), M. salvini in Colombia (Guarea guidonia; Santamaría and Franco 2000), and Ortalis canicollis in Argentina (Schinus poygamus and Rivina humilis; Caziani and Protomastro 1994). Horned Guans frequently (20\%) feed on leaves, showing habits similar to Mitu mitu which feeds on leaves with a frequency of $68 \%$ (Torres 1989), and Ortalis canicolis and Penelope perspicax, which feed on leaves with a frequency of $39 \%$ and $27 \%$, respectively (Caziani and Protomastro 1994, Muñoz 2004, Muñoz et al. 2007).

Most seeds and some fruits observed in feces were intact suggesting that Horned Guans might have a weak gizzard, allowing seeds to pass intact through their digestive tract, and thus could play an important role as dispersers in this mountain tropical ecosystem (del Hoyo and Motis 2004). However, some large seeds such as P. brachybothrya fruits, found in feces, were sometimes found completely destroyed. Horned Guans have been observed eating small pebbles, and these are more frequent in fecal samples whose content include leaf remains, suggesting the need to grind plant material in the gizzard as in other bird species (del Hoyo and Motis 2004, Bertsch and Barreto 2008). The effectiveness of the Horned Guan as a seed disperser remains to be evaluated, because individuals may remain for many hours during consecutive days in the same fruiting trees, and most seeds are defecated below the parent tree (González-García 2005a, 2012). A similar feeding behavior is reported for Pipile jacutinga in Brazil (Galleti et al. 1997).

Horned Guans are mainly arboreal and tend to forage in the mid strata of the forest. In pairs and during breeding season, males foraged higher than females, either in a fruiting trees or any other trees. In Colombia, $P$. perspicax and Chamaepetes goudotii fed in the upper strata at an average height of $9.89 \mathrm{~m}$ and $8.6 \mathrm{~m}$, respectively, and their foraging height varied over the course of the year (Ríos et al. 2006, Londoño et al. 2007). Seasonal variation in foraging height in Horned Guans remains to be evaluated.

The seasonal selection by Horned Guans of different species of fruits and different plant parts was probably dependent as much on variation of the seasonal nutritional requirements as much as on the seasonal availability of the fruits or plant parts. Both fruits and leaves consumed by guans contained about $70 \%$ water, and plant crude fiber content was similar $(17 \%$ versus $13 \%$ of dry matter (DM)), in fruits and leaves, respectively (Dierenfeld et al. 2009). However, crude protein in fruits $(9 \% \mathrm{DM})$ was considerably lower than in leaves (23\% DM), suggesting that leaves may be a supplementary source of protein or nutrients (Sun and Moermond 1997, Sun et al. 1997, Muñoz et al. 2007), and may compensate for the lack of animal protein in the diet. In captivity, Horned Guans will rarely accept invertebrates, and hand-reared chicks show little interest in mealworms or crickets (Cornejo 2009). Healthy diets for captive adults contain between 5-10\% crude protein (Tovar et al. 2009), which is well within the range of $9 \%$ and $23 \%$ of protein in fruits and leaves, respectively (Dierenfeld et al. 2009). The crude fat in Lauraceous fruits (Ocotea and Nectandra spp.) consumed pre- and early in the breeding season, could be seasonally important as it was considerably higher $(\sim 36-38 \%)$ than that in other foods eaten during those same periods. Ca:P ratios were adequate in both fruits and leaves, although leaves probably provided an essential source of both nutrients during breeding (and particularly) egglaying periods when calcium needs are elevated (Dierenfeld et al. 2009).

This study and previous ones establish that Horned Guans have a highly frugivorous-folivorous diet (Merler et al. 2001, Mikich 2002, Zaca et al. 2006) that is more specialized than that of other guans and curassows (Torres 1989, Erard et al. 1991, Santamaría and Franco 2000, Jiménez et al. 2001, del Hoyo and Motis 2004, Londoño et al. 2007, Bertsch and Barreto 2008). Green leaves are a low-quality food compared to nutritious fruits (Muñoz and Kattan 2007) and are difficult to digest because of high content of structurally complex carbohydrates, and a variety of toxic and secondary compounds (Howe and Westley 1988, Bertsch and Barreto 2008). This probably accounts for leaves being a low-intake item for birds. However, leaves could be important as a source of essential nutrients (e.g., nitrogen; Morton 1978, Jiménez et al. 2001).

The dissimilarity documented in the diets of male and female guans, involved not only the type and proportion of fruit and leaf species selected, but also the size of trees and the overall heights where they foraged. During different seasons, the 
sexes use different regions of the landscape that support different plant species; female guans with chicks use ravines more often than males, who select ridges and tall trees more often than females, presumably to broadcast their courtship calls greater distances (González-García 2005a). Unlike males, females have greater calcium needs during egg-laying and must search for and consume specific plant species to feed their chicks. Behavioral and physiological contrasts between the two sexes can thus be a cause of sexual dietary differences, which ultimately could have important habitat management implications to assure adequate survival of each sex.

The future does not bode well for Horned Guans which live at low densities, have a restricted geographic range, specialized habitat preferences, and a diet based on a small suite of cloud forest plant species. This species will likely be greatly affected by climate-change which is expected to reduce the cloud forest habitats of Mexico and increase variation and uncertainty in fruit production (Peterson et al. 2001, Rojas-Soto et al. 2012, Peterson and Navarro-Sigüenza 2016). Conservation-oriented research for effective management of the species (Santana C. and Jardel P. 1994) will be needed if the Horned Guan and its associated plant species are going to survive in the montane cloud forests of Mexico and Guatemala.

\section{ACKNOWLEDGMENTS}

We are grateful to F. R. Ramírez and I. Calzada for their support in characterizing vegetation and identifying plant species, and to the Xal Herbarium of the Instituto de Ecología, A.C. in Xalapa, Veracruz, especially F. L. Hernández and C. G. Hernández, for identifying botanical specimens. The Instituto de Historia Natural y Ecología of Tuxtla Gutiérrez, Chiapas; the Directorship of the El Triunfo Biosphere Reserve, especially its director and all the personnel at the El Triunfo field station and the El Triunfo office in Angel Albino Corzo (Jaltenango La Paz) provided important support to FGG during his fieldwork. A. Thompson, C. Tejeda, F. R. Gallardo, H. Gómez de Silva Garza, M. Neri Fajardo, P. Bubb, S. Gallo Corona, P. Mota, C. Mota provided valuable and unremitting support in the field. A very special acknowledgement goes to Chima (I. Gálvez) and Rafa (R. Solís), R. Gálvez, A. Gálvez and their respective families for sharing their great knowledge of the flora and fauna of El Triunfo and through their efforts, allowing FGG's long months and years in El Triunfo to be pleasant and more fructiferous. We thank J. Cornejo and J. Thompson for improving the manuscript with comments. We also acknowledge the collaboration and economic support of our colleagues at the following institutions:
CONACYT, Wildlife Conservation International, Brehm Fund, WildCare Institute of Saint Louis Zoo, Fondo Embajadores de Las Nubes, and Instituto de Ecología, A.C. through the Red de Biología y Conservación de Vertebrados. This work constitutes partial fulfillment of the F. González-García's doctorate in Ciencias Experimentales y Biosanitarias, Universidad de Alicante, Spain. This manuscript was written during F.G.G. sabbatical at CIIDIR, Unidad Oaxaca, Mexico. We thank I. MacGregor-Fors and R. Rueda Hernández for their assistance with the statistical analysis. Dan Brooks, the editorial team of the Wilson Journal of Ornithology, and two anonymous referees provided very helpful comments to improve the manuscript.

\section{LITERATURE CITED}

Abundis Santamaría, A. 2006. Propuesta de protocolo para el monitoreo de la población del Pavón (Oreophasis derbianus) en la Reserva de la Biosfera El Triunfo, Chiapas. Thesis. Instituto de Ecología A.C., Xalapa, Mexico.

Altmann, J. 1974. Observational study of behavior: sampling methods. Behaviour 49:227-267.

Álvarez del Toro, M. 1976. Datos biológicos del Pavón Oreophasis derbianus G. R. Gray. Universidad Autónoma de Chiapas 1:43-54.

Andrle, R. F. 1967. The Horned Guan in México and Guatemala. Condor 69:93-109.

Bertsch, C. and G. R. Barreto. 2008. Diet of the Yellowknobbed Curassow in the central Venezuelan Llanos. Wilson Journal of Ornithology 120:767-777.

BiRdLife International. 2015. Species factsheet: Oreophasis derbianus. BirdLife International, Cambridge, United Kingdom. www.birdlife.org (accessed 14 May 2015).

Brooks, D. M. (EdITOR). 2006. Conserving cracids: the most threatened family of birds in the Americas. Miscellaneous Publications of the Houston Museum of Natural Science. Number 6. Houston Museum of Natural Science, Houston, Texas, USA.

Caziani, S. M. and J. J. Protomastro. 1994. Diet of the Chaco Chachalaca. Wilson Bulletin 106:640-648.

Challenger, A. 1998. Utilización y conservación de los ecosistemas terrestres de México. Pasado, presente y futuro. Comisión Nacional para el Conocimiento y Uso de la Biodiversidad, México, Mexico.

Cóbar Carranza, A. J. 2006. Distribución actual y selección de sitios para el estudio y conservación del Pavo de Cacho (Oreophasis derbianus G.R. Gray, 1844) en los departamentos de San Marcos y Huehuetenango, Guatemala. Thesis. Universidad de San Carlos de Guatemala, Guatemala, Guatemala.

Consejo Nacional de Áreas Protegidas (CONAP). 2001. Listado de especies de fauna silvestre amenazadas de extinción (Lista Roja de fauna) y listado de especies de flora silvestre amenazadas de extinción (Lista Roja de flora). Consejo Nacional de Áreas Protegidas, Guatemala, Guatemala.

Connejo, J. 2009. Breeding programme for Horned Guan Oreophasis derbianus at Africam Safari, Mexico. International Zoo Yearbook 43:136-148. 
Cornejo, J. And E. SECAira (Editors). 2007. Memorias del III simposium internacional sobre Oreophasis derbianus. The Nature Conservancy, Guatemala, Guatemala.

Del Hoyo, J. and G. M. Kirwan. 2015. Horned Guan (Oreophasis derbianus). Handbook of the birds of the world alive (J. del Hoyo, A. Elliott, J. Sargatal, D. A. Christie, and E. de Juana, Editors). Lynx Edicions, Barcelona, Spain. www.hbw.com/node/53303 (accessed 26 Oct 2015).

Del Hoyo, J. And A. Motis. 2004. Update chapter. Pages 322-476 in Curassows and related birds (J. Delacour and D. Amadon). Second Edition. Lynx Edicions, Barcelona, Spain.

Dierenfeld, E. S., F. GonzÁlez-García, J. Cornejo, and M. MACEK. 2009. Composición nutricional de los alimentos naturales del Pavón Oreophasis derbianus en la Reserva de la Biosfera El Triunfo, Chiapas, México. IV simposio internacional de Oreophasis derbianus. The Nature Conservancy, Guatemala, Guatemala.

Eisermann, K. And C. Avendaño. 2006. Diversidad de aves en Guatemala, con una lista bibliográfica. Pages 525623 in Biodiversidad de Guatemala. Volume 1 (E. B. Cano, Editor). Universidad del Valle de Guatemala, Guatemala.

Eisermann, K., A. Burge, And G. López. 2007. Nesting records of Horned Guan (Oreophasis derbianus) on Atitlán Volcano, Guatemala. Bulletin of the Cracid Specialist Group 23:19-24.

Erard, C., M. Théry, and D. Sabatier. 1991. Diets of Tinamus major (Tinamidae), Crax alector (Cracidae), and Psophia crepitans (Psophiidae) in the French Guiana rain forest. Gibier Faune Sauvage 8:183-210.

Galleti, M., P. Martuscelli, F. Olmos, and A. Aleixo. 1997. Ecology and conservation of the Jacutinga Pipile jacutinga in the Atlantic Forest of Brazil. Biological Conservation 82:31-39.

Gómez Velasco, G., R. G. Pérez Díaz, M. A. García Villafuerte, J. E. Gómez Rodríguez, J. F. Rodríguez García, And J. S. López Bueno. 2004. Estructura y composición florística del bosque mesófilo de montaña del polígono I, Reserva de la Biosfera El Triunfo, Chiapas, México. Pages 55-76 in La Reserva de la Biosfera El Triunfo, tras una década de conservación (M. Á. Pérez-Farrera, N. Martínez-Meléndez, A. Hernández-Yáñez, and A. V. Arreola-Muñoz, Editors). Universidad de Ciencias y Artes de Chiapas, Tuxtla Gutiérrez, Mexico.

Gómez de Silva G., H., F. González-García, and M. P. Casillas-Trejo. 1999. Birds of the upper cloud forest of El Triunfo, Chiapas, Mexico. Ornitología Neotropical 10:1-26.

GonzÁlez-García, F. 1984. Aspectos biológicos del Pavón Oreophasis derbianus G.R. Gray (Aves: Cracidae) en la reserva natural "El Triunfo", municipio de Ángel Albino Corzo, Chiapas, México. Thesis. Universidad Veracruzana, Xalapa, Mexico.

GonZÁLEZ-GARCÍA, F. 1986. Description and development of the Horned Guan's chicks Oreophasis derbianus under captive conditions. XIX Congressus Internationalis Ornithologici. Ottawa, Canada.

GonZÁlez-García, F. 1988. The Horned Guan. Animal Kingdom 91:20-23.
GonZÁLEZ-GARCíA, F. 1991. Ecología y biología reproductiva del Pavón Oreophasis derbianus en la Reserva de la Biosfera El Triunfo, Chiapas, México. Congreso Ornitología Neotropical 4:69.

GonzÁlez-García, F. 1994. Behavior of Horned Guans in Chiapas, Mexico. Wilson Bulletin 106:357-365.

GonZÁlez-García, F. 1995. Reproductive biology and vocalizations of the Horned Guan Oreophasis derbianus in Mexico. Condor 97:415-426.

GonZÁlez-García, F. 1997a. Conducta de anidación del Pavón (Oreophasis derbianus: Aves, Cracidae) en la Reserva de la Biosfera El Triunfo, Chiapas, México. Pages 418-422 in The Cracidae: their biology and conservation (S. D. Strahl, S. Beaujon, D. M. Brooks, A. J. Begazo, G. Sedaghatkish, and F. Olmos, Editors). Hancock House Publishers, Blaine, Washington, USA.

GonzÁlez-García, F. 1997b. Crecimiento y desarrollo de Oreophasis derbianus bajo condiciones de cautiverio. Pages 140-145 in The Cracidae: their biology and conservation (S. D. Strahl, S. Beaujon, D. M. Brooks, A. J. Begazo, G. Sedaghatkish, and F. Olmos, Editors). Hancock House Publishers, Blaine, Washington, USA.

GonzÁlez-García, F. 1997c. Distribución del Pavón (Oreophasis derbianus) en México: pasado, presente y futuro. Pages 211-215 in The Cracidae: their biology and conservation (S. D. Strahl, S. Beaujon, D. M. Brooks, A. J. Begazo, G. Sedaghatkish, and F. Olmos, Editors). Hancock House Publishers, Blaine, Washington, USA.

GonZÁlez-GARCíA，F. 2001. Estado de conservación del Pavón Oreophasis derbianus en el campo y en cautiverio en México. Miscellaneous Publications of the Houston Museum of Natural Science 2:147-166.

GonzÁlez-García, F. 2005a. Dieta y comportamiento de forrajeo del Pavón Oreophasis derbianus en la Reserva de la Biosfera El Triunfo, Chiapas. Thesis. Universidad National Autónoma de México, México, Mexico.

GonZÁlez-García, F. 2005b. Distribución, densidad y estado poblacional del Pavón (Oreophasis derbianus) en México. Memorias del Simposium Internacional para la Conservación de Oreophasis derbianus 2:14-17.

GonZÁlez-García, F. 2007. Diet and foraging behavior of the Horned Guan (Oreophasis derbianus) at El Triunfo Biosphere Reserve, Chiapas, Mexico. Memorias del Simposium Internacional sobre Oreophasis derbianus $3: 15-27$

GonzÁlez-García, F. 2009. Biología reproductiva del Pavón (Oreophasis derbianus) y efecto del tracto digestivo sobre la germinación de semillas de Nectandra rudis (Lauraceae). IV Simposio Internacional de Oreophasis derbianus. The Nature Conservancy, Guatemala, Guatemala.

GonZÁlez-García, F. 2012. El Pavón (Oreophasis derbia$n u s)$, una especie cuasiendémica a México. El Canto del Centzontle 3:1-25.

GonzÁlez-García, F. And P. BubB. 1989. Estudio y conservación del Pavón Oreophasis derbianus en la Sierra Madre de Chiapas, México. Instituto de Ecología, Xalapa, Mexico.

GonzÁlez-García, F., D. M. Brooks, and S. D Strahl. 2001. Status of cracids in Mexico and northern Central America. Miscellaneous Publications of the Houston Museum of Natural Science 2:1-50. 
GonzÁlez-García, F., C. Porras, and J. J. Vargas. 2006a. Artificial incubation of the Horned Guans Oreophasis derbianus (Aves: Cracidae) eggs. Acta Zoológica Mexicana (n.s) 22:81-94.

González-García, F., J. A. Rivas Romero, and A. J. Cóbar Carranza. 2006b. Horned Guan (Oreophasis derbianus). Miscellaneous Publications of the Houston Museum of Natural Science 6:36-41.

Howe, H. F., E. W. Schupp, And L. C. Westley. 1985. Early consequences of seed dispersal for a Neotropical tree (Virola surinamensis). Ecology 66:781-791.

Howe, H. F. And L. C. Westley. 1988. Ecological relationships of plants and animals. Oxford University Press Inc., New York, USA.

Howell, S. N. G. AND S. WebB. 1995. A guide to the birds of Mexico and northern Central America. Oxford University Press Inc., New York, USA.

Instituto Nacional de Ecología (INE). 1999. Programa de manejo de la Reserva de la Biosfera El Triunfo. Instituto Nacional de Ecología, SEMARNAP, México, Mexico.

Jiménez, I., J. L. Parra, M. Agudelo, G. A. Londoño, and Y. MolinA. 2001. Temporal variation in the diet of Black Curassows (Crax alector, Cracidae). Miscellaneous Publications of the Houston Museum of Natural Science 2:195-211.

JoRDANO, P. 2007. Frugivores, seeds and genes: analysing the key elements of seed shadows. Pages 229-251 in Seed dispersal: theory and its application in a changing world (A. J. Dennis, E. W. Schupp, R. A. Green, and D. A. Wescott, Editors). CAB International, Wallingford, United Kingdom.

KLASING, K. C. 1998. Comparative avian nutrition. CAB International, Wallingford, United Kingdom.

LeHNER, P. N. 1996. Handbook of ethological methods. Second Edition. Cambridge University Press, Cambridge, United Kingdom.

Londoño, G. A., M. C. Muñoz, and M. M. Ríos. 2007. Density and natural history of the Sickle-winged Guan (Chamaepetes goudotii) in the central Andes, Colombia. Wilson Journal of Ornithology 119:228-238.

Long, A. And M. Heath. 1991. Flora of the El Triunfo Biosphere Reserve, Chiapas, Mexico: a preliminary floristic inventory and the plant communities of polygon I. Anales del Instituto de Biología, Universidad Nacional Autónoma de México, Serie Botánica 62:133-172.

Martin, P. And P. Bateson. 1986. Measuring behaviour: an introductory guide. Cambridge University Press, Cambridge, United Kingdom.

Méndez, O. 2000. Conducta de anidación del Pavo de Cacho Oreophasis derbianus en el Volcán Tolimán, Guatemala. Libro de Resumenes del Congreso de la Sociedad Mesoamericana para la Biología y la Conservación 4:67-68.

MÉndeZ, O. 2010. Datos biológicos del Pavo de Cacho (Oreophasis derbianus) en el Volcán Tolimán, Sololá, Guatemala. Thesis. Universidad del Valle de Guatemala, Guatemala, Guatemala.

Merler, J. A., M. A. Diuk-Wasser, and R. D. Quintana. 2001. Winter diet of Dusky-legged Guan (Penelope obscura) at the Paraná River Delta Region. Studies on Neotropical Fauna and Environment 36:33-38.
Mikich, S. B. 2002. The frugivorous diet of Penelope superciliaris (Cracidae) in semideciduous seasonal forest remnants in mid-west Paraná state, Brazil, and its relation to Euterpe edulis (Arecaceae). Ararajuba 10:207-217.

Moermond, T. C. and J. S. Denslow. 1985. Neotropical avian frugivores: patterns of behavior, morphology, and nutrition, with consequences for fruit selection. Ornithological Monographs 36:865-897.

Montes, L. 2005. Vegetación asociada a las aves (Pavo de Cacho, Oreophasis derbianus) en la Reserva Los Tarrales, Patulul, Suchitepequez, Guatemala. Instituto Técnico de Capacitación y Productividad, Guatemala, Guatemala.

Morton, E. S. 1978. Avian arboreal folivores: why not? Pages 123-130 in The ecology of arboreal folivores (G. G. Montgomery, Editor). Smithsonian Institution Press, Washington, D.C., USA.

MuÑoz, M. 2004. Morphological characteristics, nutrition and availability of fruits in the diet of the Cauca Guan (Penelope perspicax) (Aves, Cracidae), in the Otún Flora and Fauna Sanctuary, Colombia. Bulletin of the IUCN/BirdLife/WPA Cracid Specialist Group 19:3236.

Muñoz, M. C. And G. H. KatTan. 2007. Diets of cracids: how much do we know? Ornitología Neotropical 18:21-36.

Muñoz, M. C., G. A. Londoño, M. M. Ríos, And G. H. KatTAn. 2007. Diet of the Cauca Guan: explotation of a novel food source in times of scarcity. Condor 109:841-851.

Pardo Villegas, P. D. 2007. Estudio de la vegetación del Volcán San Pedro, Sololá. Thesis. Universidad de San Carlos de Guatemala, Guatemala, Guatemala.

Pérez-Farrera, M. Á., N. Martínez-Meléndez, A. HernánDeZ-YÁñez, and A. V. Arreola-Muñoz (Editors). 2004. La Reserva de la Biosfera El Triunfo, tras una década de conservación. Universidad de Ciencias y Artes de Chiapas, Tuxtla Gutiérrez, Mexico.

Peterson, A. T. and A. G. Navarro-Sigüenza. 2016. Bird conservation and biodiversity research in Mexico: status and priorities. Journal of Field Ornithology 87:121-132.

Peterson, A. T., V. Sánchez-Cordero, J. Soberón, J. Bartley, R. W. Buddemeier, and A. G. NavarroSigüEnZA. 2001. Effects of global climate change on geographic distributions of Mexican Cracidae. Ecological Modelling 144:21-30.

Pozo V., A., P. SÁnchez, and M. I. González L. 2005. Primer registro del nacimiento de Pavón (Oreophasis derbianus) en el zoológico regional "Miguel Álvarez del Toro", Tuxtla Gutiérrez, Chiapas, México. Memorias del Simposium Internacional para la Conservación de Oreophasis derbianus 2:47-50.

QuiÑónez GuZmán, J. M. 2011. Densidad poblacional e historia natural del Pavo de Cacho (Oreophasis derbianus) en la Reserva de Biosfera Sierra de las Minas, El Progreso, Guatemala. Thesis. Universidad de San Carlos de Guatemala, Guatemala, Guatemala.

Ramírez, R. F. and G. Williams-Linera. 1990. Estructura, composición florística y fitogeografía del bosque mesófilo de montaña de El Triunfo, Chiapas. XI Congreso Mexicano de Botánica. Oaxtepec, Mexico. 
Ramos, S. E. and F. GonzÁlez-García. 2009. Tiempo de tránsito y efecto sobre la germinación en semillas de cuatro especies arbóreas consumidas por el Pavón Oreophasis derbianus (Aves: Cracidae). XIII Congreso de la Sociedad Mesoamericana para la Biología y la Conservación. Belize City, Belize.

Ríos, M. M., M. C. Muñoz, AND G. A. Londoño. 2006. Natural history of the Cauca Guan (Penelope perspicax). Ornitología Colombiana 4:16-27.

Rivas, J., E. Secaira, and J. Cornejo (Editors). 2005. II Simposium Internacional Oreophasis derbianus: memorias. The Nature Conservancy, Guatemala, Guatemala.

Rivas Romero, J. A. 2008. Densidad poblacional y fenología de las plantas alimenticias del Pavo de Cacho (Oreophasis derbianus G.R. Gray 1844) en el Parque Regional Municipal Chuwanimajuyu, Sololá. Consejo Nacional de Ciencia y Tecnología, Guatemala, Guatemala.

Rivas Romero, J. A. and A. J. Cobár Carranza. 2005. Distribución actual del Pavo de Cacho (Oreophasis derbianus) en la Reserva de Biosfera Sierra de las Minas. Memorias del Simposium Internacional para la Conservación de Oreophasis derbianus 2:3-6.

Rivas Romero, J. A. and A. J. Cóbar Carranza. 2007. Distribution and conservation of the Horned Guan (Oreophasis derbianus) in Guatemala. Memorias del Simposium Internacional sobre Oreophasis derbianus 3:10-14.

Rivas-Romero, J. A. and J. R. Soto-Shoender. 2015. Filling in the gaps: evaluating the use of camera traps in the canopy to examine frugivore visits to Oreopanax echinops in the highlands of Guatemala. Southwestern Naturalist 60:366-370.

Rojas-Soto, O. R., V. Sosa, and J. F. Ornelas. 2012. Forecasting cloud forest in eastern and southern Mexico: conservation insights under future climate change scenarios. Biodiversity and Conservation 21:2671-2690

Santamaría, M. and A. M. Franco. 2000. Frugivory of Salvin's Curassow in a rainforest of the Colombian Amazon. Wilson Bulletin 112:473-481.

Santana C., E. and E. Jardel P. 1994. Research for conservation or conservation for research? Conservation Biology 8:6-7.

SeCAira, E. 2005. Avances en la conservación del hábitat del Pavo de Cacho en la cadena volcánica de Atitlán, Guatemala. Memorias del Simposium Internacional para la Conservación de Oreophasis derbianus 2:1825.

Secaira, E. And J. Cornejo (Editors). 2003. Memorias del I simposium internacional Oreophasis derbianus. VII Congreso de la Sociedad Mesoamericana para la Biología y la Conservación. Tuxtla Gutiérrez, Chiapas, México.

Secretaría del Medio Ambiente y Recursos Naturales (SEMARNAT). 2010. Protección ambiental—especies nativas de México de flora y fauna silvestrescategorías de riesgo y especificaciones para su inclusión, exclusión o cambio-lista de especies en riesgo. Norma oficial mexicana NOM-059-SEMARNAT-2010. Diario Oficial de la Federación, Segunda Sección 687(23):1-77.

Sedaghatkish, G. 1996. The importance of seed dispersers in the conservation of useful wild plant species: a case study of the avian family Cracidae. Thesis. University of Maryland, College Park, USA.

Silva, J. L. and S. D. Strahl. 1991. Human impact on populations of chachalacas, guans, and curassows (Galliformes: Cracidae) in Venezuela. Pages 37-52 in Neotropical wildlife use and conservation (J. G. Robinson and K. H. Redford, Editors). University of Chicago Press, Chicago, Illinois, USA.

Solórzano, S. 1995. Fenología de 22 especies arbóreas y su relación con la migración altitudinal del quetzal (Pharomachrus mocinno mocinno De la Llave 1832) en la Reserva de la Biosfera El Triunfo. Thesis. Universidad Nacional Autónoma de México,, México, Mexico.

Solórzano, S., S. Castillo, T. Valverde, and L. Ávila. 2000. Quetzal abundance in relation to fruit availability in a cloud forest in southeastern Mexico. Biotropica 32:523-532.

StATSoft Inc. 2003. STATISTICA: data analysis software system. Version 6. StatSoft Inc., Tulsa, Oklahoma, USA.

Strahl, S. D. and A. Grajal. 1991. Conservation of large avian frugivores and the management of Neotropical protected areas. Oryx 25:50-55.

Sun, C. AND T. C. MoERmond. 1997. Foraging ecology of three sympatric turacos in a montane forest in Rwanda. Auk 114:396-404.

Sun, C., T. C. Moermond, and T. J. Givnish. 1997. Nutritional determinants of diet in three turacos in a tropical montane forest. Auk 114:200-211.

Thery, M., C. Erard, and D. Sabatier. 1994. Diets of the Marail Guan (Penelope marail) and the Black Curassow (Crax alector). Cracid Newsletter 3:5-6.

Torres, B. 1989. La dieta del Paujil (Mitu mitu): o las vicisitudes de ser frugívoro. Boletín de Lima 66:87-90.

Tovar, G., J. Cornejo, And E. Dierenfeld. 2007. Diet and nutrition of the Horned Guan (Oreophasis derbianus) in three Mexican zoological institutions. Memorias del Simposium Internacional sobre Oreophasis derbianus $3: 43-53$.

Tovar, G., J. Cornejo, M. Macek, and E. S. Dierenfeld. 2009. Intake and digestion of Horned Guan Oreophasis derbianus diets measured in three Mexican zoos. Zoo Biology 28:319-330.

Wheelwright, N. T. 1991. How long do fruit-eating birds stay in the plants where they feed? Biotropica 23:29 40.

Williams Linera, G. 1991. Nota sobre la estructura del estrato arbóreo del bosque mesófilo de montaña en los alrededores del campamento "El Triunfo", Chiapas. Acta Botánica Mexicana 13:1-7.

Zaca, W., W. Rodrigues Silva, and F. Pedroni. 2006. Diet of the Rusty-margined Guan (Penelope superciliaris) in an altitudinal forest fragment of southeastern Brazil. Ornitología Neotropical 17:373-382. 